\title{
A Novel Analytical Method for the Simultaneous Estimation of Remogliflozin and Metformin Hydrochloride by UPLC/PDA in Bulk and Formulation Application to the Estimation of Product Traces
}

\author{
Bulk ve Formülasyon Uygulamalarında Eser Ürünlerin Kestirimi için \\ UPLC/PDA ile Remogliflozin ve Metformin Hidroklorürü Eşzamanlı \\ Belirleyebilen Yeni Bir Analitik Yöntem
}

\author{
(D) Mohan Rao TAMMISETTY1*, (D) Balasekhara Reddy CHALLA2², (D) Srinivasa Babu PUTTAGUNTA 3 \\ 1 Jawaharlal Nehru Technological University, Kakinada, Andhra Pradesh, India \\ 2Vagdevi College of Pharmacy, Andhra Pradesh, India \\ 3Vignan Pharmacy College, Andhra Pradesh, India
}

ABSTRACT

Objectives: A selective and novel method has been optimized for the evaluation of remogliflozin and metformin hydrochloride in bulk and in the formulation and cleaning of samples by UPLC-PDA in bulk and formulation and product traces.

Materials and Methods: The principle analytes were eluted with phosphate buffer ( $\mathrm{pH}: 4.5)$ : acetonitrile (60:40\%, v/v) as the mobile phase using the Spherisorb C18, $5 \mu \mathrm{m}, 4.6 \mathrm{~mm} \times 150 \mathrm{~mm}$ analytical column with a $1.0 \mathrm{~mL} / \mathrm{min}$ flow rate and a $10 \mu \mathrm{L}$ sample volume at $245 \mathrm{~nm}$ in a photodiode array detector.

Results: The retention times of remogliflozin and metformin hydrochloride were $3.017 \mathrm{~min}$ and $5.011 \mathrm{~min}$ with a total run time of 8 min. The curve indicates that the correlation coefficient $\left(r^{2}\right)$ was superior with a value of 1.000 in the linear range of $10 \mathrm{ng} / \mathrm{mL}-100.0 \mathrm{ng} / \mathrm{mL}$ for remogliflozin and $50 \mathrm{ng} / \mathrm{mL}-500.0 \mathrm{ng} / \mathrm{mL}$ for metformin hydrochloride. The correlation coefficient $\left(r^{2}\right)$ for metformin hydrochloride was found to be 1.000 . The lower limits of quantification and detection for remogliflozin and metformin hydrochloride were found to be $10 \mathrm{ng} / \mathrm{mL}$ and $50 \mathrm{ng} / \mathrm{mL}$, and $5 \mathrm{ng} / \mathrm{mL}$ and 10 $\mathrm{ng} / \mathrm{mL}$, respectively.

Conclusion: The developed method was validated and applied to the bulk drug estimation and drug formulation and cleaning samples. All the results obtained with this method was accurate and precise.

Key words: Remogliflozin, metformin hydrochloride, bulk drug, formulation, cleaning samples, UPLC-PDA

ÖZ

Amaç: UPLC-PDA ile yığında ve formülasyon uygulamalarında remogliflozin ve metformin hidroklorürün eş zamanlı tayini ve örnek temizliğinin belirlenmesi için seçici ve yeni bir yöntem optimize edilmiștir.

Gereç ve Yöntemler: Temel analitler, hareketli faz olarak fosfat tamponu ( $\mathrm{pH}: 4,5)$ : asetonitril (60: 40\%, v/v) ile, Spherisorb C18, 5 um, 4,6 mm x 150 $\mathrm{mm}$ analitik kolon kullanılarak, 1,0 mL/dk akış hızında fotodiyot array dedektörü ile $245 \mathrm{~nm}$ 'de 10 uL örnek hacmi ile elüe edilmiştir.

Bulgular: Remogliflozin ve metformin hidroklorürün alıkonma süreleri sırasıyla 3,017 dakika ve 5,011 dakikaydı ve toplam çalışma süresi 8 dakikaydı. Eğri, korelasyon katsayısının $\left(r^{2}\right)$, remogliflozin için $10 \mathrm{ng} / \mathrm{mL}-100,0 \mathrm{ng} / \mathrm{mL}$ ve metformin hidroklorür için $50 \mathrm{ng} / \mathrm{mL}-500,0 \mathrm{ng} / \mathrm{mL}$ doğrusal aralıkta 1,000 değeriyle üstün olduğunu göstermektedir. Metformin hidroklorür için korelasyon katsayısı $\left(r^{2}\right)$ 1,000 olarak bulundu. Remogliflozin ve metformin hidroklorür için alt kantifikasyon ve saptama sınırları sırasıyla $10 \mathrm{ng} / \mathrm{mL}$ ile $50 \mathrm{ng} / \mathrm{mL}$ ve $5 \mathrm{ng} / \mathrm{mL}$ ile $10 \mathrm{ng} / \mathrm{mL}$ olarak bulunmuştur.

Sonuç: Geliştirilen yöntem valide edilmiş ve yığında, ilaç formülasyonunda ve temizleme numunelerinde ilaç belirlenmesi için uygulanmıştır. Bu yöntemle elde edilen tüm sonuçlar doğru ve kesindir.

Anahtar kelimeler: Remogliflozin, metformin hidroklorür, yığın ilaç, formülasyon, temizleme numuneleri, UPLC-PDA

*Correspondence: mohanjntuk.sch@gmail.com, Phone: +91-7997545957, ORCID-ID: orcid.org/0000-0002-2977-673X

Received: 04.03.2020, Accepted: 08.06.2020

Turk J Pharm Sci, Published by Galenos Publishing House. 


\section{INTRODUCTION}

Remogliflozin etabonate [5-methyl-4-(4-(1-methylethoxy) benzyl)-1-(1-methylethyl)-1H-pyrazol-3-yl 6-0-(ethoxycarbonyl)$\beta$-D-glucopyranoside] is a pro-drug of remogliflozin. It belongs to the glifozin class of drugs. This drug is primarily used in cases of non-alcoholic steatohepatitis and type-2 diabetes. Remogliflozin inhibits the sodium-glucose transport proteins, which are responsible for glucose reabsorption in the kidney. Metformin (N,N-dimethylimido dicarbonimidicdiamide) is used to lower blood sugar in those with type 2 diabetes. It is also used to treat polycystic ovary syndrome. Metformin is a dimethyl biguanide that reduces elevated blood glucose levels primarily by reducing hepatic glucose production and improving peripheral tissue sensitivity to insulin.'

Based on a literature survey, there are no existing analytical methods for this new formulation, i.e., remogliflozin and metformin hydrochloride. Several methods have been developed for other gliflozin drugs, such as dapagliflozin, empagliflozin, and canagliflozin, with other combination of gliptins such as saxagliptin and linagliptin and with biguanides such as metformin. ${ }^{2-20}$ For the remogliflozin and metformin hydrochloride combination, there was a lack of sensitive analytical methods for the identification and quantification in bulk and in formulations. Moreover, there was no sensitive analytical method with the $10 \mathrm{ng} / \mathrm{mL}$ sensitivity necessary to quantify the product traces left in manufacturing areas after a product changeover.

\section{MATERIALS AND METHODS}

Remogliflozin (Figure 1), metformin hydrochloride (Figure 2), and high-purity acetonitrile were from (J.T. Baker, Phillipsburg,

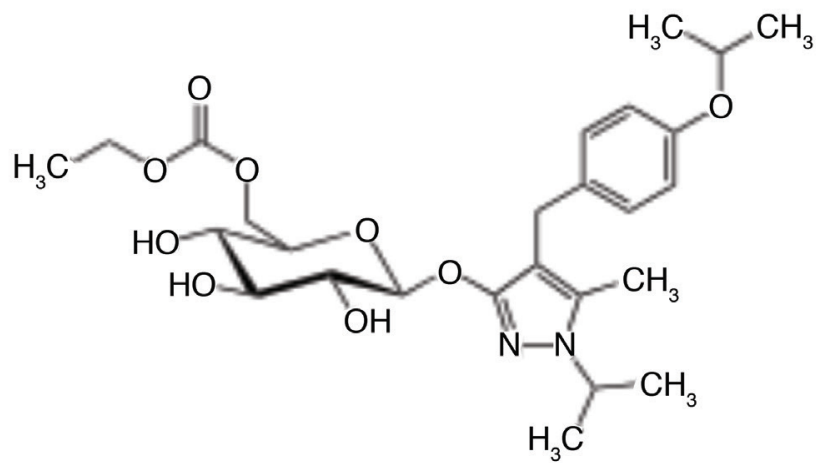

Figure 1. Remogliflozin<smiles>CN(C)C(=N)NC(=N)N</smiles>

NJ, USA); water was from a (Milli-Q system, Millipore, Bedford, MA, USA); potassium dihydrogen phosphate and sodium dihydrogen phosphate were from (Merck Pvt. Ltd, Worli, Mumbai); and ortho phosphoric acid was from (Merck Pvt. Ltd, Worli, Mumbai). The formulation was provided by the Yountus Life Sciences, Andhra Pradesh, India.

\section{Preparation of standard solutions}

Metformin hydrochloride and remogliflozin etabonate standard stock solutions were prepared by placing 25.38 $\mathrm{mg}$ and $126.92 \mathrm{mg}$, respectively in $25 \mathrm{~mL}$ volumetric flasks and then adding $10 \mathrm{~mL}$ diluent and sonicating for 3 minutes. Then, the volume was adjusted to $25 \mathrm{~mL}$ with diluent. From the stock $25 \mathrm{~mL}, 1 \mathrm{~mL}$ was removed to a $1000 \mathrm{~mL}$ volumetric flask and the volume adjusted to $25 \mathrm{~mL}$ with diluent. From this $1000 \mathrm{~mL}, 1 \mathrm{~mL}$ was removed to a $10 \mathrm{~mL}$ volumetric flask and the volume adjusted to the mark with diluent to obtain a 100 $\mathrm{ng} / \mathrm{mL}$ solution of remogliflozin and a $500 \mathrm{ng} / \mathrm{mL}$ solution of metformin hydrochloride.

\section{Preparation of buffer ( $p H$ 4.5)}

Potassium dihydrogen phosphate (13.9 g) and disodium hydrogen phosphate $(35.04 \mathrm{~g})$ were weighed precisely and added to a $1000 \mathrm{~mL}$ beaker. Water $(500 \mathrm{~mL}$ ) was added and stirred with a glass rod to completely dissolve the salts, and then the volume was adjusted to $1000 \mathrm{~mL}$ with water. The prepared buffer solution was adjusted to $\mathrm{pH}$ to 4.5 with dilute ortho phosphoric acid.

\section{Preparation of the mobile phase}

From the $1000 \mathrm{~mL}$ buffer, $600 \mathrm{~mL}$ buffer was removed and added to a $1000 \mathrm{~mL}$ mobile-phase bottle. Acetonitrile $(400 \mathrm{~mL})$ was added to the buffer and the buffer degassed to prepare $1000 \mathrm{~mL}$ of mobile phase.

\section{Preparation of diluent}

The diluent was prepared by adding $2000 \mathrm{~mL}$ of water to a $4000 \mathrm{~mL}$ mobile-phase bottle and then adding $2000 \mathrm{~mL}$ of methanol and degassing to obtain $4000 \mathrm{~mL}$ of diluent.

\section{Optimization of chromatographic conditions}

After a series of trials, the final chromatographic conditions were determined as follows. The mobile phase was a buffer with $\mathrm{pH} 4.5$ and acetonitrile $(60: 40 \% \mathrm{v} / \mathrm{v})$, and the stationary phase was a Spherisorb $C_{18}$ column with dimensions $5 \mu \mathrm{m}, 4.6$ $\mathrm{mm} \times 150 \mathrm{~mm}$ to obtain the best peak shape. The separation of remogliflozin and metformin hydrochloride was good at 245 $\mathrm{nm}$ with a column temperature of $25^{\circ} \mathrm{C}$, a sample compartment temperature of $10^{\circ} \mathrm{C}$, a flow rate of $1.0 \mathrm{~mL} / \mathrm{min}$, and a sample volume of $10 \mu \mathrm{L}$.

\section{Assay sample preparation}

One tablet (REMO-M) containing remogliflozin $100 \mathrm{mg}$ and metformin $500 \mathrm{mg}$ was added to a $1000 \mathrm{~mL}$ volumetric flask, dissolved in diluent, and the volume adjusted to $1000 \mathrm{~mL}$. This preparation was considered as the stock solution. From the stock solution, $1 \mathrm{~mL}$ was removed and added to a $1000 \mathrm{~mL}$ volumetric flask and the volume adjusted to the mark with

Figure 2. Metformin 
diluent to obtain $100 \mathrm{ng} / \mathrm{mL}$ of remogliflozin and $500 \mathrm{ng} / \mathrm{mL}$ of metformin hydrochloride.

\section{Validation of the analytical method}

Validation was performed for the developed method within stringent limits to test the efficiency of this method., ${ }^{1.2}$

To verify that the system produced consistent results with the optimized method, the standard was injected 6 times with the criteria of \% relative standard deviation (RSD) for retention time (RT) and area not more than (NMT) 2.0\%, the oretical plates not less than (NLT) 3000 plates, tailing factor NMT 1.5, and resolution NLT 4.

\section{Selectivity}

To verify the method validation in terms of selectivity and exactness, triplicate preparations of $100 \%$ concentration, i.e., $100 \mathrm{ng} / \mathrm{mL}$ of remogliflozin and $500 \mathrm{ng} / \mathrm{mL}$ of metformin hydrochloride, were injected. Then, one blank was also injected to test for carryover. The limit of specificity is that it should pass the system suitability criteria, and there should not be an RT shift for any of the three preparations.

\section{Precision}

After passing the specificity and system suitability criteria, the method was verified for system precision and method precision with the limit of \% RSD for the RT and area NMT $2 \%$. The intermediate precision was verified on the next day with another column by setting the limit as \% RSD for the RT and NMT $2 \%$ for the area.

\section{Accuracy and recovery}

To verify the method accuracy, triplicate preparations were prepared at $80 \%, 100 \%$, and $120 \%$ of the $100 \%$ concentrations (100 ng/mL for remogliflozin and $500 \mathrm{ng} / \mathrm{mL}$ for metformin hydrochloride) by spiking the standard into the diluent. The percent recovery was calculated with acceptance criteria of 95\%-105\%.

\section{Linearity}

The method linearity was verified with 5 dilutions of the $100 \%$ concentration: $10 \mathrm{ng} / \mathrm{mL}, 20 \mathrm{ng} / \mathrm{mL}, 50 \mathrm{ng} / \mathrm{mL}, 75 \mathrm{ng} / \mathrm{mL}$, and $100 \mathrm{ng} / \mathrm{mL}$ for remogliflozin and $50 \mathrm{ng} / \mathrm{mL}, 100 \mathrm{ng} / \mathrm{mL}, 250 \mathrm{ng} /$ $\mathrm{mL}, 375 \mathrm{ng} / \mathrm{mL}$, and $500 \mathrm{ng} / \mathrm{mL}$ for metformin hydrochloride. The acceptance criterion of the regression coefficient $\left(R^{2}\right)$ was NLT 0.99 .

\section{Robustness}

To verify the method efficiency when minor changes occurred in optimized method parameters such as mobile-phase composition, column temperature and flow, and buffer $\mathrm{pH}$, these parameters were tested with the criteria that they should pass the system suitability criteria.

\section{Lower level of quantification (LOQ)}

By considering the $10 \%$ concentration of the target concentration, the sample was injected into the system with the acceptance criteria S/N ratio NLT 10. From the lower $L O Q$, preparations of different concentrations were injected to identify the detectability with the acceptance criteria 3:1, and the minimum detectability was five times out of six injections from the same concentration.

\section{Lower level of quantification precision}

LOQ precision was verified with the limit NMT $2.0 \%$ for the RT and area.

\section{Assessment of stability of the standard and mobile phase}

The prepared mobile phase and standard preparations were verified for stability up to 72 hours.

\section{Degradation behavior}

To test the developed method for stability indicating method the formulation sample was subjected to acid and base, and thermal, photo, and peroxide degradation were carried with the aim of detection of degradants in the chromatogram. Acid degradation was carried out by adding $20 \mathrm{~mL}$ of $0.1 \mathrm{~N} \mathrm{HCL}$ to the stock solution, and from that $1 \mathrm{~mL}$ was removed and added to a $1000 \mathrm{~mL}$ volumetric flask and the volume adjusted to the mark. In the same way, $2 \mathrm{~mL} 1 \mathrm{~N} \mathrm{NaOH}$ was added to test for base degradation. To test for thermal degradation, the sample was subjected to heat at $105^{\circ} \mathrm{C}$ for 3 hours and the sample prepared as per the assay procedure. For photo degradation, the sample was exposed to ultraviolet light with an intensity NLT 2000 lux power for 6 hours and the sample prepared as per the assay procedure. For peroxide degradation, $2 \mathrm{~mL} \mathrm{H}_{2} \mathrm{O}_{2}$ were added to the stock $1000 \mathrm{~mL}$ volumetric flask, $1 \mathrm{~mL}$ was removed and added to a $1000 \mathrm{~mL}$ flask, the volume adjusted to the mark with the diluent, and the sample was injected.

\section{Filter compatibility}

To evaluate the impact of polyvinylidene fluoride (PVDF) and Nylon filters on the assay results, the samples were analyzed after passage through the filters.

Recovery of the Swabs from the stainless steel (SS) and glass and epoxy plate

Due to the high sensitivity (nanogram level) of the developed method, it can be used in cleaning method validation or for surface cleaning sample quantification at the time of product changeover in the manufacturing area. Hence, the method applicability for the quantification of surface cleaning samples in the manufacturing area was verified. Three surfaces (SS, glass, epoxy) were selected based on the manufacturing area designs as per the cGmp. Sterile swabs were taken and the recovery verified from the SS plate, glass plate, and epoxy plate with the acceptance criteria NLT 90\% with the LOQ concentration $(10 \mathrm{ng} / \mathrm{mL}$ remogliflozin and 50 $\mathrm{ng} / \mathrm{mL}$ metformin). The recovery was calculated by pouring the $1 \mathrm{~mL}$ sample before the final concentration (after the first dilution in $1000 \mathrm{~mL}$ ) of the standard preparation on the plates. After drying, the swab was added to a $10 \mathrm{~mL}$ volumetric flask and the volume adjusted to the mark with diluent.

\section{Statistical analysis}

The data were processed through the $Q$ Sight software, and the results were calculated as mean and \pm SD for the accuracy and 
the RSD was calculated for the precision. The coefficient of regression was also calculated in the linearity parameter.

\section{RESULTS}

Clear separation and good resolution without any carryover was achieved with this method as shown in Figure 3-6. The system suitability acceptance criteria were also found to be satisfactory as shown in Table 1, 2. For the system precision parameters, the \% RSD of RT and area for remogliflozin and metformin hydrochloride achieved $0.02 \%$ and $0.03 \%$, and $0.01 \%$ and $0.03 \%$ as shown in Table 3 against the limit NMT $2.0 \%$. For the method precision parameters, the \%RSD of RT and area for remogliflozin and metformin hydrochloride achieved $0.03 \%$ and $0.02 \%$, and $0.02 \%$ and $0.05 \%$ against the limit NMT $2.0 \%$ as shown in Table 4 . The linearity parameter was quantified by peak area vs. concentration methodology. Different concentrations from $10 \mathrm{ng} / \mathrm{mL}$ to $100 \mathrm{ng} / \mathrm{mL}$ standard solutions for remogliflozin and from $50 \mathrm{ng} / \mathrm{mL}$ to $100 \mathrm{ng} / \mathrm{mL}$

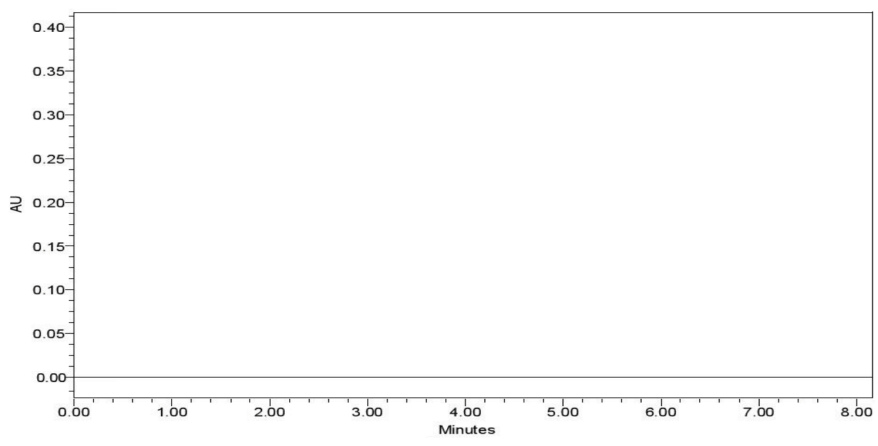

Figure 3. Blank chromatogram

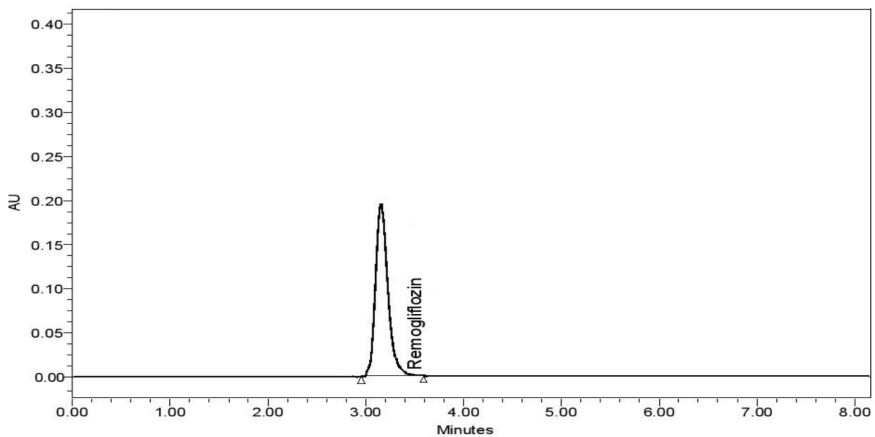

Figure 4. Specificity chromatogram of remogliflozin

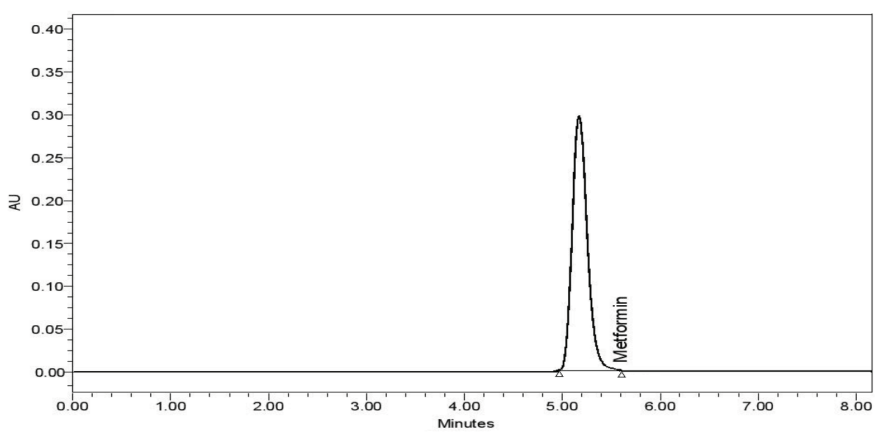

Figure 5. Specificity chromatogram of metformin were prepared and injected into the system. The recovery for $80 \%, 100 \%$, and $120 \%$ was more than $99 \%$ against the acceptance criteria of $95 \%-105 \%$ as shown in Table 5 and Figure 7-9. The calculated regression coefficient for remogliflozin and metformin hydrochloride was 1.000 as shown in Figure 10, 11. To evaluate the method's capability of producing precise results with minor variations in flow, mobile-phase composition, $\mathrm{pH}$ and column temperature variations, a test for robustness was performed. The results are shown in the Table 6 . The results prove that the method was stable to produce consistent results with minor variations of the method parameters. The compatibility of the filters was verified with PVDF and Nylon filters. The assay for remogliflozin and metformin hydrochloride was more accurate (100.2\% for remogliflozin and $99.7 \%$ for metformin hydrochloride) with the PVDF filter compared with the Nylon filter $(99.8 \%$ for remogliflozin, $98.9 \%$ for metformin hydrochloride) as shown in Table 7 . To demonstrate that the

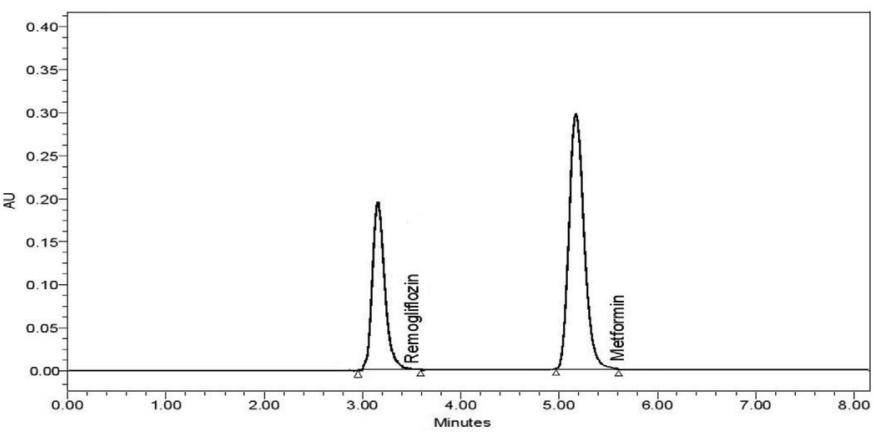

Figure 6. System suitability chromatogram of remogliflozin and metformin

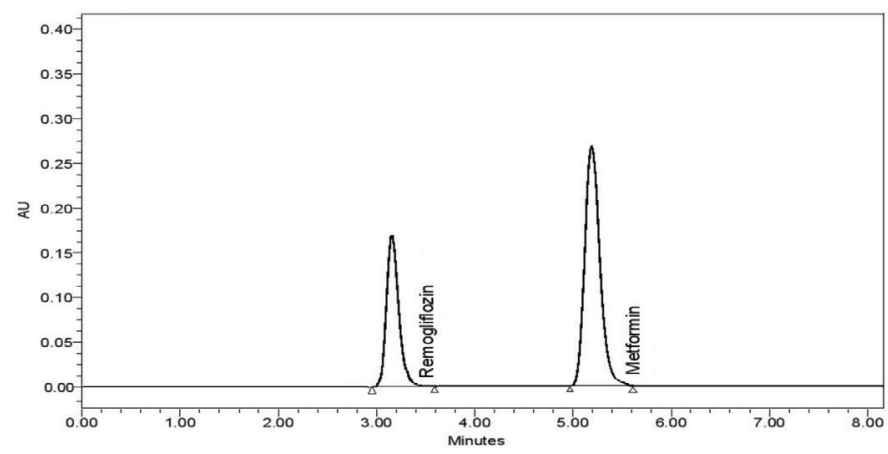

Figure $7.80 \%$ accuracy level chromatogram of remogliflozin and metformin

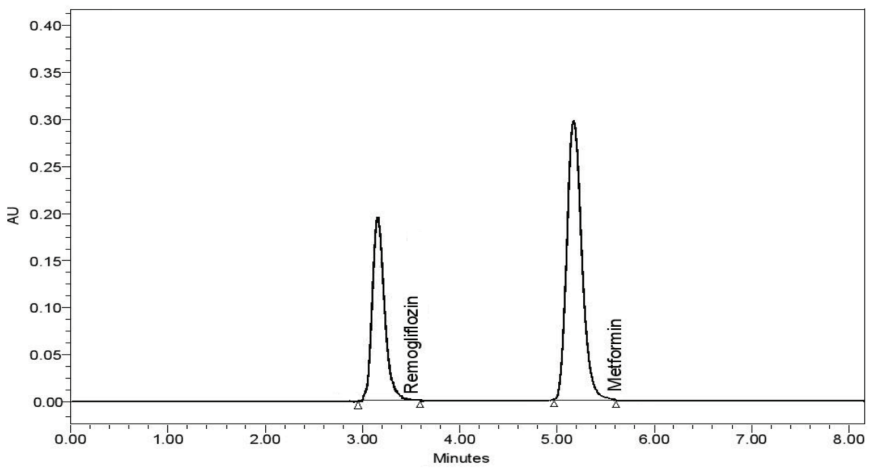

Figure 8. $100 \%$ accuracy level chromatogram of remogliflozin and metformin 
Table 1. Specificity data

\begin{tabular}{llllllll} 
S. no & Injection & Remogliflozin & RT & Area & Metformin & RT & Area \\
\hline 01 & Blank & Not detected & NA & NA & Not detected & NA & NA \\
\hline 02 & 01 & Detected & 3.018 & 983652 & Detected & 5.011 & 1215689 \\
\hline 03 & 02 & Detected & 3.017 & 983259 & Detected & 5.012 & 1215697 \\
\hline
\end{tabular}

RT: Retention time

Table 2. System suitability data

\begin{tabular}{lll} 
Parameter & Remogliflozin & Metformin \\
\hline Retention time & 3.017 & 5.011 \\
\hline Area & 983717 & 1216101 \\
\hline Asymmetry & 0.8 & 1.1 \\
\hline Theoretical plates & 6200 & 7800 \\
\hline Resolution & 5.4 & \\
\hline$\%$ RSD of area & 0.02 & 0.03 \\
\hline
\end{tabular}

RSD: Relative standard deviation

\section{Table 3. System precision data}

\begin{tabular}{lllll} 
Drug name & \multicolumn{2}{l}{ Remogliflozin } & Metformin \\
\hline Injection & RT & Area & RT & Area \\
\hline 01 & 3.018 & 983251 & 5.011 & 1215641 \\
\hline 02 & 3.017 & 983652 & 5.012 & 1216121 \\
\hline 03 & 3.018 & 983569 & 5.011 & 1215624 \\
\hline 04 & 3.018 & 983569 & 5.011 & 1215698 \\
\hline 05 & 3.017 & 983957 & 5.012 & 1215564 \\
\hline 06 & 3.018 & 983267 & 5.011 & 1216521 \\
\hline Average & 3.018 & 983544 & 5.011 & 1215862 \\
\hline SD & 0.0005 & 263.0821 & 0.0005 & 380.1435 \\
\hline \% RSD & 0.02 & 0.03 & 0.01 & 0.03 \\
\hline
\end{tabular}

RSD: Relative standard deviation, SD: Standard deviation, RT: Retention time

method was stable, acid degradation was carried out, and the degradants were identified at $4.019 \mathrm{~min}$ and $6.017 \mathrm{~min}$ as shown in Figure 12. In base degradation, the degradants were detected at $4.516 \mathrm{~min}$ and $5.802 \mathrm{~min}$ and $7.224 \mathrm{~min}$ as shown in Figure 13. In light degradation, the degradants were detected at $3.681 \mathrm{~min}$ and $5.844 \mathrm{~min}$ and $6.192 \mathrm{~min}$ as shown in Figure 14. In thermal degradation, the degradants were detected in $3.841 \mathrm{~min}$ and $4.412 \mathrm{~min}$ and $5.942 \mathrm{~min}$ and $6.454 \mathrm{~min}$ as shown in the Figure 15. In the peroxide stress condition, the degradants occurred at $3.642 \mathrm{~min}$ and $4.235 \mathrm{~min}$ and $6.94 \mathrm{~min}$ and $7.421 \mathrm{~min}$ as shown in Figure 16. The $L O Q$ for remogliflozin was $10 \mathrm{ng} / \mathrm{mL}$ and 50 $\mathrm{ng} / \mathrm{mL}$ with $\mathrm{S} / \mathrm{N}$ ratios of 11.8 and 10.8 as shown in Table 8 . The $L O Q$ precision was also performed to evaluate the repeatability at the lower end of the quantification range. The obtained \% RSD of the area for remogliflozin and metformin hydrochloride
Table 4. Method precision data

\begin{tabular}{lllll} 
Drug name & \multicolumn{2}{l}{ Remogliflozin } & Metformin \\
\hline Injection & RT & Area & RT & Area \\
\hline 01 & 3.016 & 983958 & 5.012 & 1215632 \\
\hline 02 & 3.015 & 983587 & 5.011 & 1216985 \\
\hline 03 & 3.017 & 983695 & 5.012 & 1215896 \\
\hline 04 & 3.016 & 983895 & 5.013 & 1215348 \\
\hline 05 & 3.015 & 983958 & 5.012 & 1215835 \\
\hline 06 & 3.017 & 983689 & 5.011 & 1215798 \\
\hline Average & 3.016 & 983797 & 5.012 & 1215916 \\
\hline SD & 0.0009 & 159.7586 & 0.0008 & 559.8081 \\
\hline \% RSD & 0.03 & 0.02 & 0.02 & 0.05 \\
\hline
\end{tabular}

RSD: Relative standard deviation, SD: Standard deviation, RT: Retention time

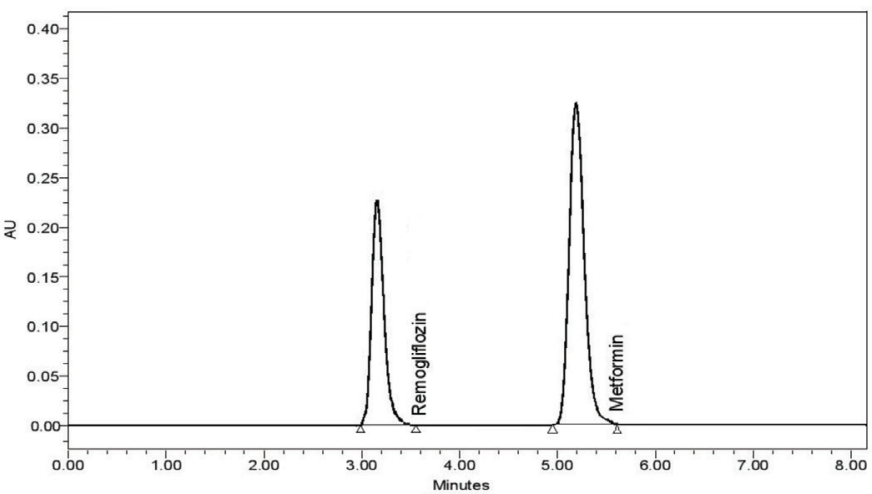

Figure 9. $120 \%$ accuracy level chromatogram of remogliflozin and metformin

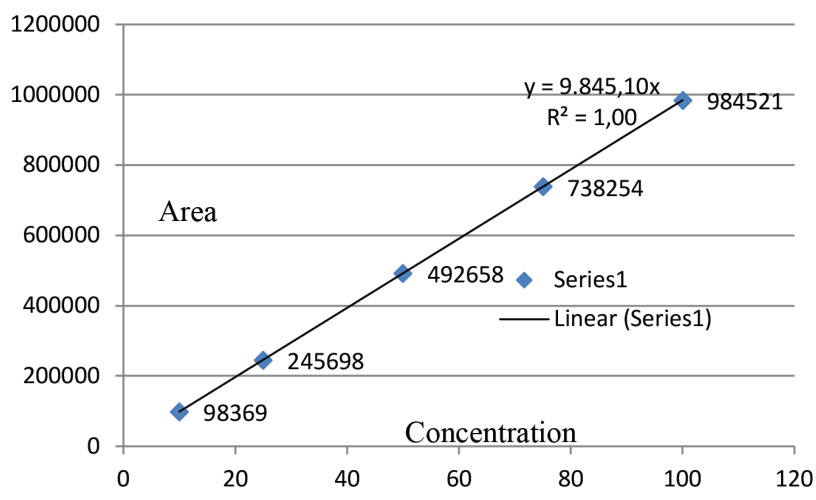

Figure 10. Linearity graph of remogliflozin 


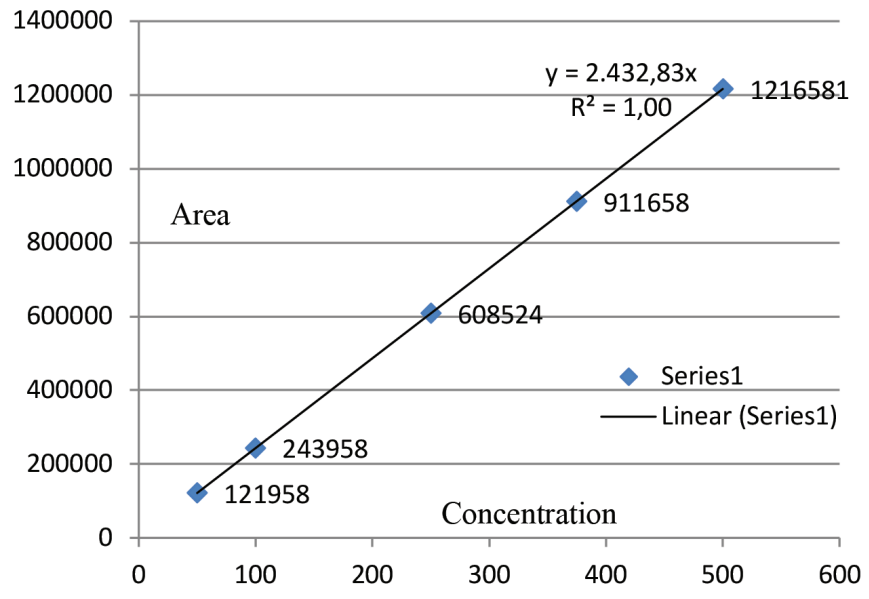

Figure 11. Linearity graph of metformin

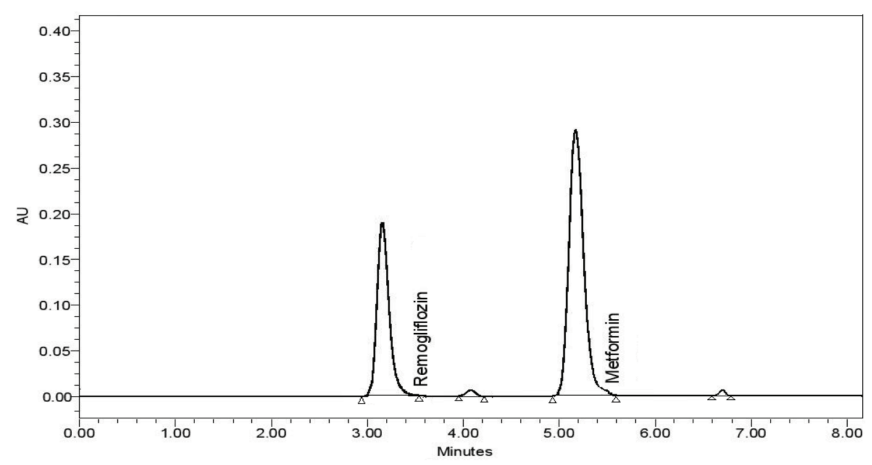

Figure 12. Acid degradation chromatogram

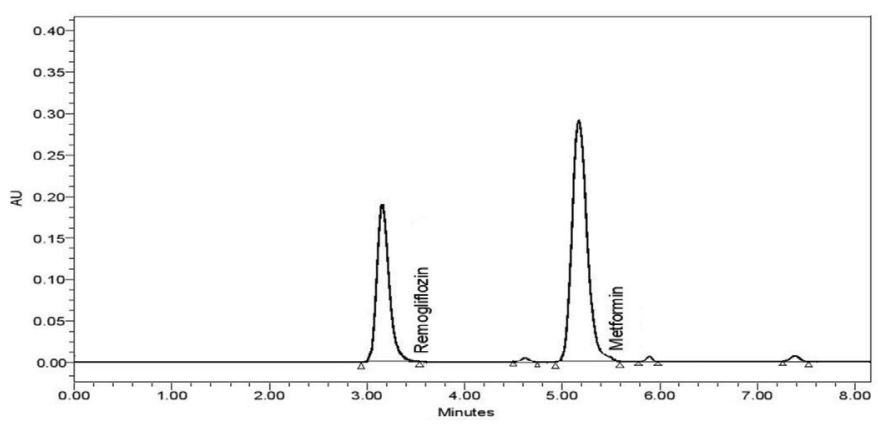

Figure 13. Base degradation chromatogram

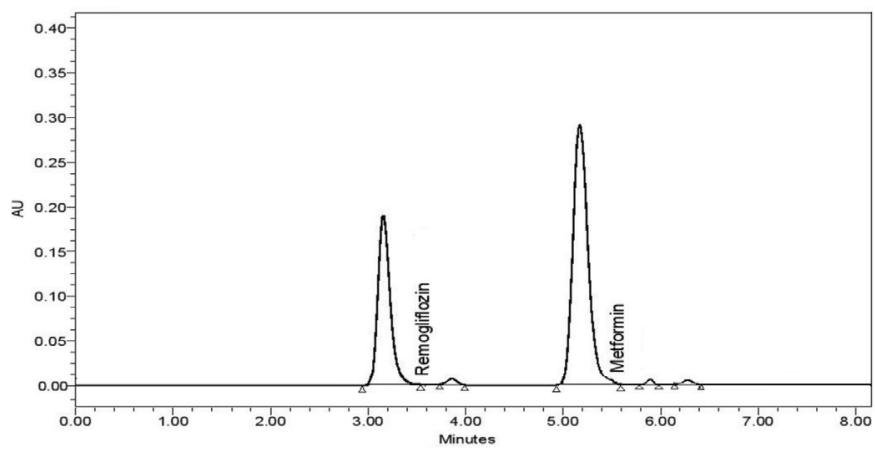

Figure 14. Photo degradation chromatogram was 0.03 and $0.18 \%$ as shown in Table 9. The lower limit of detection (LOD) for remogliflozin was $5 \mathrm{ng} / \mathrm{mL}$ and $10.0 \mathrm{ng} / \mathrm{mL}$ with an S/N ratio of 3.8 and 3.5 as shown in Table 10, and clear detection is shown in Figure 17. For the intermediate precision parameter, the \% RSD of area for remogliflozin and metformin hydrochloride achieved on day- 1 was $0.03 \%$ and 0.02 and on the next day $0.06 \%$ and $0.02 \%$ against the limit NMT $2.0 \%$ as shown in Table 11. Solution and mobile-phase stability were established, and it was confirmed that the solution and mobile phase were stable for 72 hours as per the data furnished in Table 12 . The purity angle and purity threshold were good as shown in Table 13. From these results, we can conclude that the method was stable. The method was verified for robustness as well as interday and intraday precision. The LOQ and LOD were identified by injecting the lower concentrations with the $\mathrm{S} / \mathrm{N}$ ratio criteria, and the drugs were detected six times out of six injections. The obtained \% RSD showing the capability of

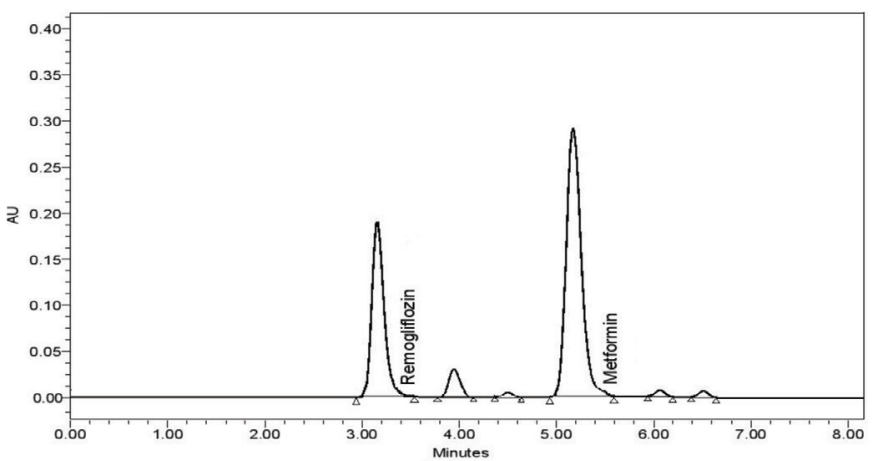

Figure 15. Thermal degradation chromatogram

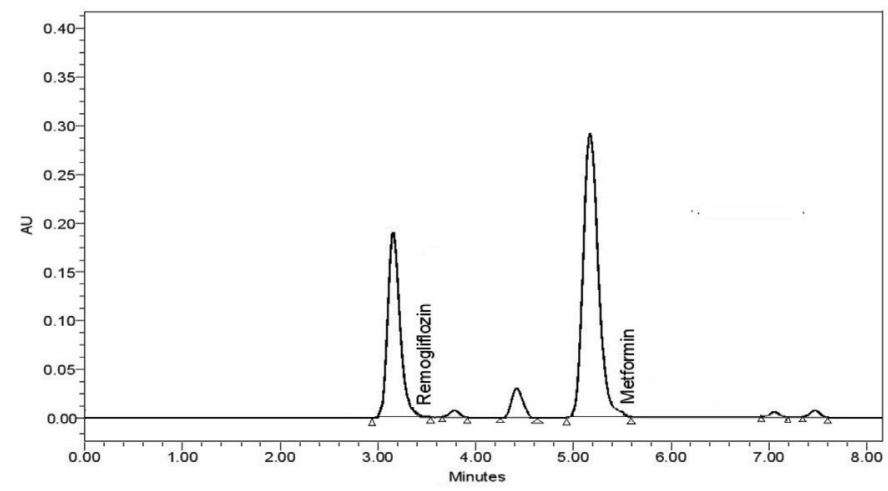

Figure 16. Peroxide degradation chromatogram

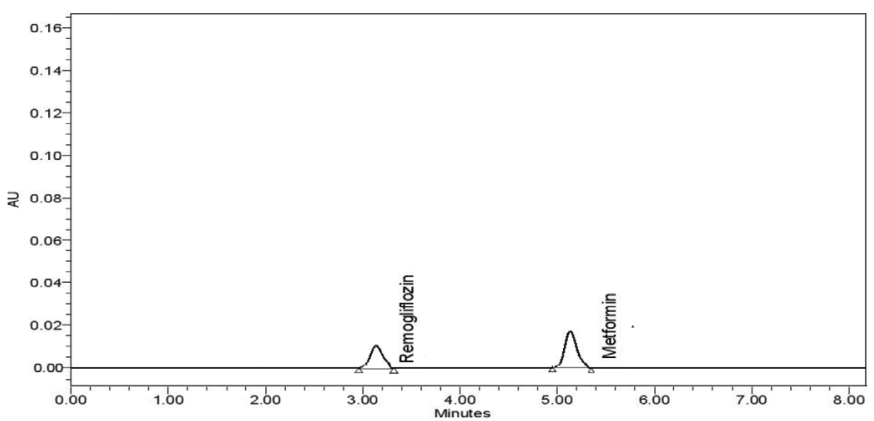

Figure 17. Limit of detection chromatogram 
also quantifying the activities at lower concentrations. Then, the method was applied for recovery on a SS plate, a glass plate and an epoxy plate with the aim of recovery NLT 90\% to prove its utility in cleaning method validation. The obtained average recovery for remogliflozin and metformin hydrochloride was above $94 \%$ as shown in Table 14-16.

\section{DISCUSSION}

During method optimization, organic solvents were initially used as the mobile phase with water in varying composition. However, neither compound was detected. Then, buffer was used with organic solvent such as acetonitrile in different ratios and at varying $\mathrm{pH}$ with the Spherisorb $\mathrm{C}_{18}, 5 \mu \mathrm{m}$,

Table 5. Accuracy and recovery data

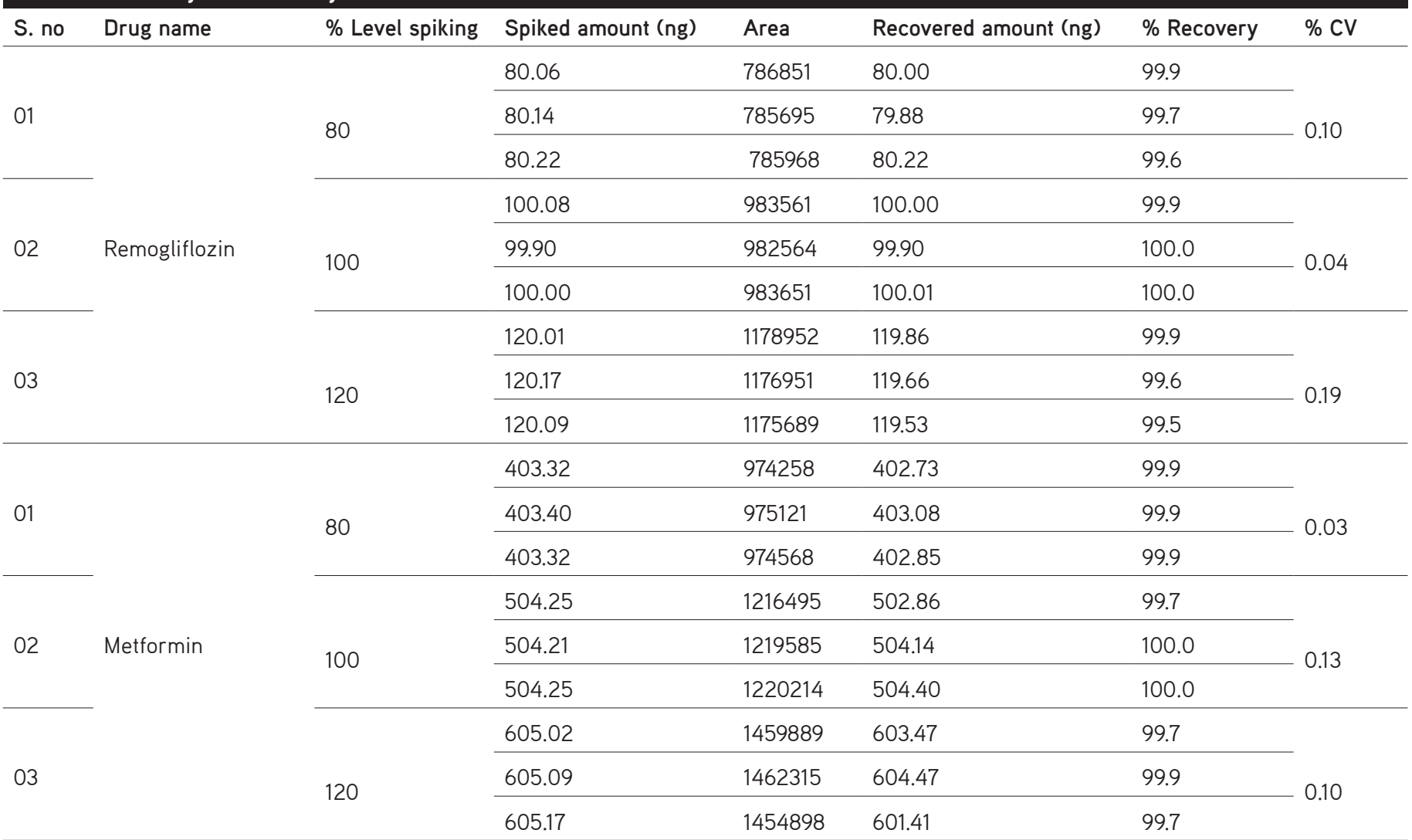

\section{Table 6. Robustness data}

\begin{tabular}{|c|c|c|c|c|c|c|c|c|}
\hline \multirow{2}{*}{ Condition } & \multirow{2}{*}{ Value } & \multicolumn{4}{|c|}{ Remogliflozin } & \multicolumn{3}{|c|}{ Metformin } \\
\hline & & RT & Area & Asymmetry & Resolution & RT & Area & Asymmetry \\
\hline \multirow{2}{*}{ Flow } & $0.8 \mathrm{~mL} / \mathrm{min}$ & 3.112 & 984526 & 0.84 & 5.2 & 5.112 & 1218987 & 1.12 \\
\hline & $1.2 \mathrm{~mL} / \mathrm{min}$ & 2.997 & 982652 & 0.80 & 5.1 & 4.998 & 1214236 & 1.14 \\
\hline \multirow{2}{*}{$\begin{array}{l}\text { Mobile phase composition } \\
\text { (buffer:acetonitrile) }\end{array}$} & $55 / 35 \mathrm{v} / \mathrm{v}$ & 3.201 & 984265 & 0.82 & 5.3 & 5.042 & 1210565 & 1.13 \\
\hline & $65 / 45 \mathrm{v} / \mathrm{v}$ & 2.895 & 982674 & 0.84 & 5.3 & 5.001 & 1201985 & 1.19 \\
\hline \multirow{3}{*}{$\mathrm{pH}$} & 4.0 & 2.965 & 984652 & 0.82 & 5.5 & 5.125 & 1219875 & 1.13 \\
\hline & 4.5 & 3.017 & 983875 & 0.80 & 5.4 & 5.012 & 1215897 & 1.10 \\
\hline & 5.0 & 2.912 & 982159 & 0.83 & 5.3 & 4.958 & 1219837 & 1.17 \\
\hline Column temperature & 27 & 2.986 & 983687 & 0.85 & 5.3 & 4.985 & 1219765 & 1.15 \\
\hline
\end{tabular}

RT: Retention time 
Table 7. Filter compatibility

\begin{tabular}{lll} 
Drug name & $0.2 \mu \mathrm{m}$ PVDF filter assay & $0.2 \mu \mathrm{m}$ Nylon filter assay \\
\hline Remogliflozin & $100.2 \%$ & 99.8 \\
\hline Metformin & $99.7 \%$ & 98.9 \\
\hline Difference & $0.4 \%$ for remogliflozin, $0.8 \%$ for metformin \\
\hline Suitability & PVDF 0.2 $\mu \mathrm{M}$ filter & \\
\hline
\end{tabular}

PVDF: Polyvinylidene fluoride

\section{Table 8. Limit of quantitation}

\begin{tabular}{llll} 
Drug name & Area & LOQ & S/N ratio \\
\hline Remogliflozin & 98526 & $10 \mathrm{ng} / \mathrm{mL}$ & 11.8 \\
\hline Metformin & 122652 & $50 \mathrm{ng} / \mathrm{mL}$ & 10.8
\end{tabular}

LOQ: Limit of quantitation, S/N: Signal to noise

Table 9. Limit of quantitation precision

\begin{tabular}{lllll} 
Drug name & \multicolumn{3}{l}{ Remogliflozin } & Metformin \\
\hline Injection & RT & Area & RT & Area \\
\hline 01 & 3.017 & 98537 & 5.013 & 122561 \\
\hline 02 & 3.015 & 98579 & 5.012 & 122565 \\
\hline 03 & 3.018 & 98567 & 5.012 & 122869 \\
\hline 04 & 3.017 & 98521 & 5.011 & 122875 \\
\hline 05 & 3.017 & 98585 & 5.011 & 122856 \\
\hline 06 & 3.018 & 98596 & 5.011 & 122359 \\
\hline Average & 3.017 & 98564 & 5.012 & 122681 \\
\hline SD & 0.0011 & 29.24665 & 0.0008 & 216.8616 \\
\hline$\%$ RSD & 0.04 & 0.03 & 0.02 & 0.18 \\
\hline
\end{tabular}

RT: Retention time, RSD: Relative standard deviation, SD: Standard deviation

\section{Table 10. Limit of detection}

\begin{tabular}{llll} 
Drug name & Area & LOD & S/N ratio \\
\hline Remogliflozin & 49263 & $5 \mathrm{ng} / \mathrm{mL}$ & 3.8 \\
\hline Metformin & 24530 & $10 \mathrm{ng} / \mathrm{mL}$ & 3.5 \\
\hline
\end{tabular}

LOD: Limit of detection, S/N: Signal to noise
$4.6 \mathrm{~mm} \times 150$ column. Finally, the method was found to be optimized with the conditions of mobile phase [buffer $\mathrm{pH}$ 4.5 and acetonitrile (60:40\% v/v), wavelength $245 \mathrm{~nm}$, flow rate of $1.0 \mathrm{~mL} / \mathrm{min}$, column temperature of $25^{\circ} \mathrm{C}$, sample compartment temperature of $10^{\circ} \mathrm{C}$, and sample volume of $10 \mu \mathrm{L}$. With this method, both active compounds, i.e., remogliflozin and metformin hydrochloride eluted at 3.017 min and 5.011 min with good resolution and symmetry. Following method optimization, the method was validated as per $\mathrm{ICH}$ guidelines. As per the results obtained in the method validation, there was no interference of the blank or carryover problem, even at the $L O Q$. Both the $L O Q$ and LOD of this method were verified practically in the instrument with $\mathrm{S} / \mathrm{N}$ ratio criteria. The results were found to be satisfactory. The method was applied to degraded samples to verify its usefulness within the shelf-life period (stability indicating nature). The method detected degradants successfully in all the degradation conditions. As the method was highly sensitive, it was applied to the quantification of cleaning samples of manufacturing area surfaces with the criteria of recovery NLT 90\%. Based on the results of recovery from SS, glass, and epoxy plates, this method has proven its capability to analyze cleaning validation samples at the time of products changeover in the manufacturing area.

\section{CONCLUSION}

Based on the results obtained in the current study, the developed method was very sensitive, accurate, linear, and economical. Due to the short duration of the chromatographic program, more samples can be analyzed within a short period, which will be helpful in the industry at a time when multiple products are manufactured continuously. The method met all the predefined acceptance criteria. With this method, the sample of bulk and formulation samples and surface cleaning samples can be analyzed. As the method is capable of detecting degradant formulations, bulk shelf-life samples can also be analyzed by using this method.

Table 11. Ruggedness data

\begin{tabular}{|c|c|c|c|c|c|c|}
\hline Drug name & Injection & Day-1 & Day-2 & Drug name & Day-1 & Day-2 \\
\hline \multirow{4}{*}{ Remogliflozin } & 01 & 983562 & 983256 & \multirow{7}{*}{ Metformin } & 1216525 & 1215698 \\
\hline & 02 & 984452 & 983265 & & 1216956 & 1215669 \\
\hline & 04 & 983598 & 983645 & & 1215152 & 1215678 \\
\hline & 05 & 983675 & 983759 & & 1214985 & 1215345 \\
\hline Average & & 983766 & 983497 & & 1215977 & 1215727 \\
\hline Standard deviation & & 338.7662 & 206.9661 & & 774.7693 & 239.0219 \\
\hline$\%$ RSD & & 0.03 & 0.02 & & 0.06 & 0.02 \\
\hline
\end{tabular}

RSD: Relative standard deviation 
Table 12. Standard and mobile-phase stability

\begin{tabular}{|c|c|c|c|c|}
\hline Drug name & Remogl & & Metform & \\
\hline Injection & RT & Area & RT & Area \\
\hline Initial & 3.018 & 983251 & 5.011 & 1215641 \\
\hline 24 & 3.017 & 982991 & 5.012 & 1215232 \\
\hline 36 & 3.017 & 982854 & 5.012 & 1214985 \\
\hline 72 & 3.015 & 982568 & 5.011 & 1214121 \\
\hline Average & 3.016 & 982925 & 5.012 & 1215023 \\
\hline SD & 0.0012 & 262.1334 & 0.0005 & 595.0297 \\
\hline \% RSD & 0.04 & 0.03 & 0.01 & 0.05 \\
\hline
\end{tabular}

RT: Retention time, RSD: Relative standard deviation, SD: Standard deviation

\section{Table 13. Degradation study on drug product data}

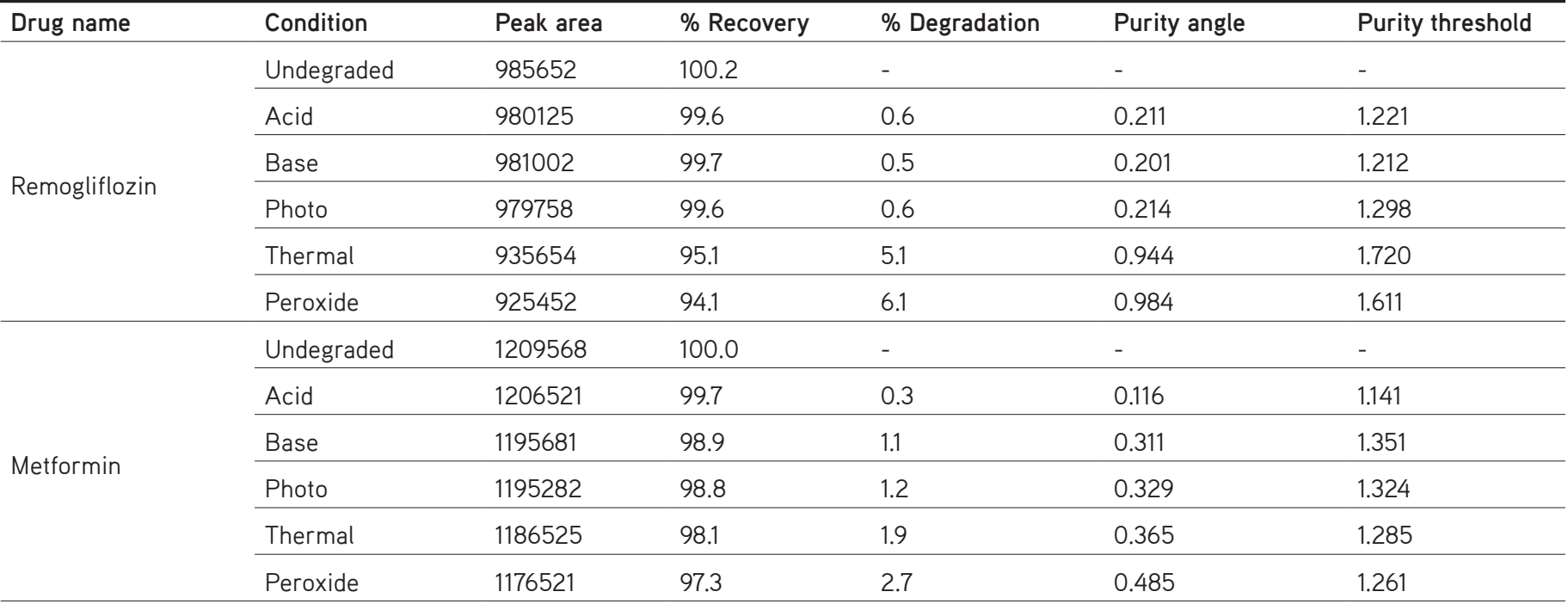

Table 14. Recovery on stainless steel plate of $100 \%$ spiking

\begin{tabular}{llll} 
Drug name & $\begin{array}{l}\text { Amount spiked } \\
(\mathrm{ng} / \mathrm{mL})\end{array}$ & $\begin{array}{l}\text { Recovery } \\
(\mathrm{ng} / \mathrm{mL})\end{array}$ & \% Recovery \\
\hline Remogliflozin & 10.17 & 9.66 & 95.0 \\
\hline Metformin & 50.48 & 48.83 & 96.7 \\
\hline
\end{tabular}

Table 15. Recovery on glass plate of $100 \%$ spiking

\begin{tabular}{llll} 
Drug name & $\begin{array}{l}\text { Amount spiked } \\
(\mathrm{ng} / \mathrm{mL})\end{array}$ & $\begin{array}{l}\text { Recovery } \\
(\mathrm{ng} / \mathrm{mL})\end{array}$ & \% Recovery \\
\hline Remogliflozin & 10.32 & 9.77 & 94.6 \\
\hline Metformin & 50.88 & 48.71 & 95.7 \\
\hline
\end{tabular}

Table 16. Recovery on epoxy plate of $100 \%$ spiking

\begin{tabular}{llll} 
Drug name & $\begin{array}{l}\text { Amount spiked } \\
(\mathrm{ng} / \mathrm{mL})\end{array}$ & $\begin{array}{l}\text { Recovery } \\
(\mathrm{ng} / \mathrm{mL})\end{array}$ & \% Recovery \\
\hline Remogliflozin & 10.13 & 9.71 & 95.9 \\
\hline Metformin & 50.40 & 48.16 & 95.5 \\
\hline
\end{tabular}

\section{ACKNOWLEDGMENTS}

The authors are grateful to Yontus Life Sciences Pvt. Ltd, Guntur, India for providing support to carry out the analysis work.

Conflicts of interest: No conflict of interest was declared by the authors. The authors alone are responsible for the content and writing of the paper.

\section{REFERENCES}

1. Elizabeth K Hussey, Anita Kapur, Robin O Connor Semmes, Wenli Tao. Safety, pharmacokinetics and pharmacodynamics of remogliflozin etabonate, a novel SGLT2 inhibitor and metformin when co-administered in subjects with type 2 diabetes mellitus. BMC Pharmacol Toxicol. 2013;1:625-634.

2. Padmaja N, Babu MS, Veerabhadram G. Development and validation of UV spectrophotometric method for Simultaneous estimation of empagliflozin and metformin hydrochloride in bulk drugs and combined dosage forms. 2016;1:15-26. 
3. Sowjanya P. RP-HPLC Method development of metformin in pharmaceutical dosage form. J Pharm Anal. 2012;4:9-20.

4. Pandit V, Pai RS, Devi K, Singh G, Narayana S, Suresh S. Development and validation of the liquid chromatographic method for simultaneous estimation of metformin, pioglitazone, and glimepiride in pharmaceutical dosage forms. Pharm Methods. 2012;1:9-13.

5. Sundar SP, Vasanthi R, Raja AM, Dutt RK, Rao KNV, Ramana. Development and validation of RP-HPLC method for simultaneous estimation of dapagliflozin and metformin in bulk and in synthetic mixture. World $\mathrm{J}$ Pharm Pharm Sci. 2017;7:2139-2150.

6. Aswini R, MM, Eswarudu, Srinivasa Babu P. A novel rp-hplc method for simultaneous estimation of dapagliflozin and saxagliptin in bulk and pharmaceutical dosage form. Int J Pharm Sci Res. 2018;12:5161-5167.

7. Komminenai V, Chowdhary KPR, Prasad SVUM. Development of a new stability indicating RP-HPLC method for simultaneous estimation of saxagliptin and dapagliflozin and its validation as per ICH Guidelines. Int J Pharm Sci Res. 2017;9:2920-2932.

8. Daswadkar SC, Roy MA, Walode SG, Mahendra Kumar CB. Quality by Design approach for the development and validation of Saxagliptin by RP-HPLC with application to formulated forms. Int J Pharm Sci Res. 2016;4:1670-1677.

9. Caglar S, Rahmi ALP. A Validated high performance liquid chromatography method for the determination of saxagliptin and metformin in bulk. A Stability Indicating Study. J Anal Bioanal Tech. 2014:S12.

10. Prasad PBN, Satyanarayana K, Krishna Mohan G. Development and Validation of a Method for simultaneous determination of metformin and saxagliptin in formulation by RP-HPLC. Am J Analyt Chem. 2015;5:737742 .

11. Kommineni V, Chowdary KPR. Prasad SVUM. Development of a new stability indicating RP-HPLC method for simultaneous estimation of metformin hydrochloride and canagliflozin and its validation as per $\mathrm{ICH}$ guidelines. Int J Pharm Sci Res. 2017;8:3427-3435.
12. D-Douza S, Krishna M, Sushmitha GS, Vasantharaju SG. Stability Indicating assay method development and validation to simultaneously estimate metformin hydrochloride and canagliflozin by RP-HPLC. Curr Trends Biotechnol Pharm. 2016;10:334-342.

13. Gaware D, Patil RN, Harole M. A Validated Stability Indicating Rp-HPLC Method for simultaneous determination of metformin and canagliflozin in pharmaceutical formulation. World J Pharm Pharm Sci. 2015;4:631-640.

14. Wafaa A. Zaghary, Shereen Mowaka, Moataz S. Hendy. Comparative Liquid chromatographic study for concurrent determination of canagliflozin and metformin in combined tablets. J Analyt Methods Chem. 2017;2017:9197230.

15. Ayoub BM. Development and validation of simple spectrophotometric and chemo metric methods for simultaneous determination of empagliflozin and metformin. Applied to recently approved pharmaceutical formulation. Spectrochim Acta A Mol Biomol Spectrosc. 2016;168:118-122.

16. Ayoub BM. UPLC simultaneous determination of empagliflozin, linagliptin and metformin. RSC Advances. 2015:5:95703-95709.

17. Mowaka S, Ayoub BM. Comparative study between UHPLC-UV and UPLC-MS/MS methods for determination of alogliptin and metformin in their pharmaceutical combination. Pharmazie. 2017:72:67-72.

18. Murthy TG, Geethanjali J. Development of a validated RP-HPLC method for simultaneous estimation of metformin hydrochloride and rosuvastatin calcium in bulk and in-house formulation. J Chromatogr Sep Tech. 2014;5:1-7.

19. Snyder LR, Kirkland JJ, Glajch JL. Practical HPLC method development. $2^{\text {nd }}$ ed. New York; Wiley Interscience; 1979:374-383.

20. ICH Harmonized Tripartite Guideline: Text on Validation of Analytical Procedures, Text and Methodology, Q2 (R1), International Conference on Harmonization, Geneva; 2005:1-17. 